\title{
ANALYTICAL REDUNDANCY IN CONTROL SYSTEMS FOR UNMANNED AIRCRAFT AND OPTIONALLY PILOTED VEHICLES
}

\author{
Bogusław Dolęga, Grzegorz Kopecki, Andrzej Tomczyk
}

Katedra Awioniki i Sterowania, Wydział Budowy Maszyn i Lotnictwa, Politechnika Rzeszowska (Department of Avionics and Control Systems, Faculty of Mechanical Engineering and Aeronautics, Rzeszów University of Technology), al. Powstańców Warszawy 12, 35-959 Rzeszów dolbog@prz.edu.pl, GKopecki@prz.edu.pl,A.Tomczyk@prz.edu.pl

\begin{abstract}
The article presents key properties of a module intended to estimate non-measurable state variables of an aircraft (a fixed-wing aircraft). Sample calculations are applicable to the MP-02A Czajka light Optionally Piloted Vehicle (OPV). The quality of flight parameter values' estimation is illustrated by comparing flight parameters of the MP-02A Czajka aircraft recorded during actual flight with estimated values of respective parameters calculated during simulation of selected sensor faults. This experiment allows to evaluate the usefulness of the analytical redundancy mechanism that determines attitude parameters (roll, pitch and heading angles) and navigational variables (airspeed, altitude and geographic coordinates).
\end{abstract}

Keywords: on-board measurement systems, analytical redundancy, UAV, optionally piloted vehicles.

\section{INTRODUCTION}

In recent years, a dynamic growth of unmanned aerial vehicles (UAVs) can be witnessed. They have found their applications primarily in military operations, but utilization of UAVs in civil applications, involving mostly observation and transportation tasks has been considered more and more commonly (and implemented in practice). Large courier companies are already offering experimental small package delivery systems and development of complex delivery networks is contemplated. Airbus has been conducting advanced research of unmanned aerial taxis. These plans bring to life completely new logistic challenges, such as those related to organization of the air traffic in an airspace. The fundamental postulate is to ensure high level of flight safety for manned aircraft and UAVs in shared airspace. One of the elements of this strategy would be to ensure high reliability of UAV and OPV control systems, including their measurement systems and navigation systems as well. 
Measurement of parameters (state variables) describing the current situation of the aircraft is necessary for automatic as well as for manual control of the aircraft. It is necessary to achieve the assumed reliability of on-board instruments, especially in IFR conditions and in the case of UAVs or OPVs. A typical means for achieving the required operational reliability would be to use hardware redundancy. However, redundancy of instruments and systems increases weight and raises costs of aircraft production. An alternative way of improving instruments' reliability would be to use analytical redundancy, involving analytical determination of flight parameters which can not be measured directly (e.g. due to malfunction of some sensors), based on other available measurement signals. Usually, this would provide less accurate data, which would be sufficient, however, to verify whether the available instruments and measurement systems operate correctly and to control the aircraft in emergency situations.

Automatic control of the aircraft's attitude and location on the predefined flight path requires measurement of multiple variables. Currently, a typical minimum set of on-board instruments and measurement systems includes: AHRS - the Attitude and Heading Reference System, MAG - magnetometer - which determines the magnetic heading, ADC - Air Data Computer and GPS - Global Positioning System receiver. The required reliability level of instrument readings is defined depending on the type of aircraft and on its function. Usually, a single measurement system can not ensure the required reliability, hence the classic approach involving the use of redundant instruments or measurement systems. Figure 1 illustrates typical variants of systems which ensure redundancy for the on-board instruments and measurement systems.

Transport aircraft measurement systems usually utilize triple measurement sub-systems. Output signals from these sub-systems are compared by a supervising module (version A). In the simplest case of decision-making algorithms, either by voting or rejection of extreme values, the module which has produced the correct measurement is selected. Such solution with triple measurement systems translates to higher costs and higher weight of the measurement system and, therefore, it would be better to use double measurement sub-systems with a module that calculates some state variables based on the available, independent measurements (version B). The third module employs the analytical redundancy principle. Estimated values of state variables are sufficient to verify whether all hardware-based modules are operating correctly and to select the correctly-functioning module in case of discrepancies between their outputs. In the simplest solution (version C), correct operation of a single hardware module is evaluated by comparing its output with the estimated value of a signal. In specific cases, it is possible to replace the signal of a malfunctioning measuring sensor signal with the estimated variable value.

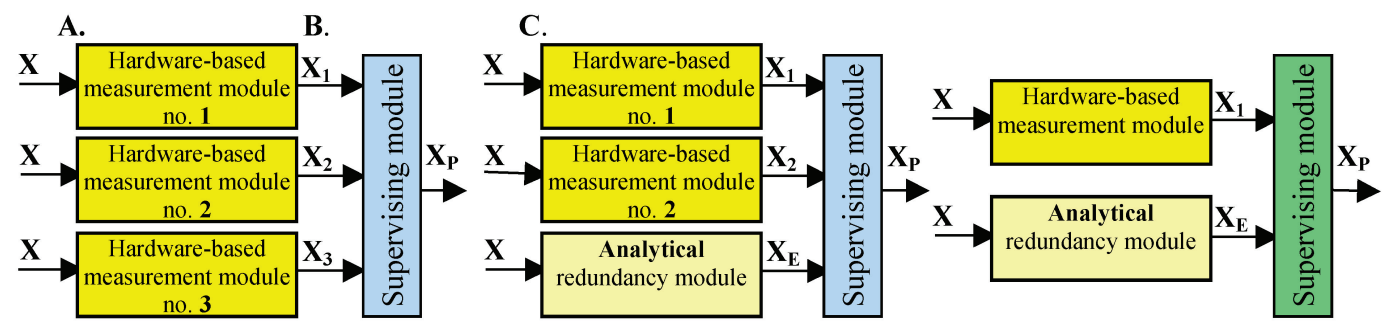

Fig. 1. Block diagrams of typical measurement system redundancy solutions, where: $\mathbf{X}$ - physical state variables, $\mathbf{X}_{1}$, $\mathbf{X}_{2}, \mathbf{X}_{3}-$ measurement vectors, $\mathbf{X}_{\mathbf{E}}-$ estimated measurement vector, $\mathbf{X}_{\mathbf{P}}-$ output measurement vector [Tomczyk, 2015] 
The analytical redundancy is the area of interest of many design teams who develop control systems for light aircraft [1-4], which includes the team from the Department of Avionics and Control Systems [5-10]. All three options of measurement systems improving the reliability of on-board control systems are utilized in control and navigation systems of UAVs and OPVs. If possible and justified, the number of hardware-based measuring modules is reduced. This paper describes estimation rules for selected state variables which are required to ensure control over the aircraft, assuming malfunctions of individual measurement systems. It also discuses cases when only some of the AHRS and GPS signals are missing, and when two devices are failing at the same time. Table 1 shows the selection (non-exhaustive list) of analyzed cases of non-measurable signal estimation.

Table 1. Sample breakdown of measured signals and estimated signals [Tomczyk, 2015]

\begin{tabular}{|c|c|c|c|c|c|c|c|c|c|c|c|c|c|c|c|c|c|c|c|c|c|c|}
\hline $\begin{array}{l}\text { Types of measurement } \\
\text { module malfunctions }\end{array}$ & \multicolumn{110}{|c|}{ Measurement signals - state variables } \\
\hline ADC & MAG & AHRS & GPS & $\mathrm{p}$ & $\mathrm{q}$ & $\mathrm{r}$ & $\mathrm{a}_{\mathrm{X}}$ & $\mathrm{a}_{\mathrm{Y}}$ & $\mathrm{a}_{\mathrm{Z}}$ & $\Phi$ & $\Theta$ & $\Psi$ & $\lambda$ & $\phi$ & $\mathrm{H}_{\mathrm{G}}$ & $\mathrm{GS}$ & $\mathrm{KD}$ & $\mathrm{V}_{\mathrm{I}}$ & $\mathrm{V}_{\mathrm{T}}$ & $\mathrm{H}_{\mathrm{B}}$ & $\Psi_{\mathrm{M}}$ & $\mathrm{t}_{\mathrm{S}}$ \\
\hline 1 & 1 & 1 & 1 & 1 & 1 & 1 & 1 & 1 & 1 & 1 & 1 & 1 & 1 & 1 & 1 & 1 & 1 & 1 & 1 & 1 & 1 & 1 \\
\hline 1 & 0 & 1 & 1 & 1 & 1 & 1 & 1 & 1 & 1 & 1 & 1 & 1 & 1 & 1 & 1 & 1 & 1 & 1 & 1 & 1 & $\mathrm{E} 1$ & 1 \\
\hline 1 & 1 & 1 & 2 & 1 & 1 & 1 & 1 & 1 & 1 & 1 & 1 & 1 & 1 & 1 & $\mathrm{E} 2$ & 1 & 1 & 1 & 1 & 1 & 1 & 1 \\
\hline 1 & 1 & 1 & 0 & 1 & 1 & 1 & 1 & 1 & 1 & 1 & 1 & 1 & $\mathrm{E} 6$ & $\mathrm{E} 6$ & $\mathrm{E} 2$ & $\mathrm{E} 3$ & $\mathrm{E} 3$ & 1 & 1 & 1 & 1 & 1 \\
\hline 1 & 1 & 4 & 1 & 1 & 1 & 1 & 0 & 0 & 0 & $\mathrm{E} 8$ & $\mathrm{E} 12$ & $\mathrm{E} 4$ & 1 & 1 & 1 & 1 & 1 & 1 & 1 & 1 & 1 & 1 \\
\hline 1 & 0 & 0 & 1 & 0 & 0 & $\mathrm{E} 9$ & 0 & 0 & 0 & $\mathrm{E} 9$ & $\mathrm{E} 12$ & $\mathrm{E} 7$ & 1 & 1 & 1 & 1 & 1 & 1 & 1 & 1 & $\mathrm{E} 1$ & 1 \\
\hline 1 & 0 & 3 & 1 & 0 & 0 & $\mathrm{E} 9$ & 1 & 1 & 1 & $\mathrm{E} 9$ & $\mathrm{E} 11$ & $\mathrm{E} 7$ & 1 & 1 & 1 & 1 & 1 & 1 & 1 & 1 & 1 & 1 \\
\hline 1 & 1 & 4 & 0 & 1 & 1 & 1 & 0 & 0 & 0 & $\mathrm{E} 10$ & $\mathrm{E} 12$ & $\mathrm{E} 4$ & $\mathrm{E} 6$ & $\mathrm{E} 6$ & $\mathrm{E} 2$ & $\mathrm{E} 3$ & $\mathrm{E} 3$ & 1 & 1 & 1 & 1 & 1 \\
\hline 0 & 0 & 1 & 1 & 1 & 1 & 1 & 1 & 1 & 1 & 1 & 1 & 1 & 1 & 1 & 1 & 1 & 1 & $\mathrm{E} 5$ & $\mathrm{E} 5$ & $\mathrm{E} 13$ & $\mathrm{E} 1$ & $\mathrm{E} 5$ \\
\hline 0 & 1 & 1 & 2 & 1 & 1 & 1 & 1 & 1 & 1 & 1 & 1 & 1 & 1 & 1 & 0 & 1 & 1 & $\mathrm{E} 5$ & $\mathrm{E} 5$ & 0 & 1 & 0 \\
\hline
\end{tabular}

Columns in table 1 show, in sequence, causes of some of the measurement signal failures (from the left) and the table lists variables which are measured using AHRS, ADC, GPS receiver and using the magnetometer (MAG). Commonly known labels of variables have been used, however the table includes symbols which describe the state of the measurement system or the state of a measurement variable:

$\mathbf{1}$ - correct operation of the measurement system, direct measurement of a variable,

$\mathbf{0}$ - measurement system does not work, the variable value can not be estimated,

2 - GPS works in 2D mode, missing GPS altitude signal,

3 - angular velocity is not measured by the AHRS,

4 - linear acceleration is not measured by the AHRS,

$\mathbf{E j}$ - a variable is estimated using the algorithm with the number j, e.g. E1, E8, E12.

\section{ESTIMATION OF NON-MEASURABLE MEASUREMENT SIGNALS}

Application of analytical redundancy is conditioned upon availability of measurement signals independently of the operation of hardware modules, as a whole system. Diagnostic systems of the supervising module shall determine the credibility of individual signals and the type of malfunction of basic measurement systems. Based on this a relevant algorithm shall be activated to estimate the value of non-available state variables. Below we discuss selected 
calculation procedures for estimated state variables which are run with the measurement frequency of available variables $[5,8,9,10,13]$.

\section{E0. Calculation of wind speed and wind direction, comparison of altitudes}

If GPS receiver signal is lost, dead reckoning is possible, provided that current wind speed and current wind direction information is available. Based on the ground speed (GS), the track angle (KD), the true airspeed $\left(\mathrm{V}_{\mathrm{T}}=\mathrm{TAS}\right)$ and the geographic heading $(\Psi)$ momentary wind speed components in geographic system of reference $\mathrm{U}_{\mathrm{N}}$ and $\mathrm{U}_{\mathrm{E}}$ are calculated and averaged using a recursive filter with $\mathrm{T}_{\mathrm{U}}$ time constant equal to $\mathrm{U}_{\mathrm{NE}}$ and $\mathrm{U}_{\mathrm{EE}}$. Average drift angle (KZ) is also calculated. When GPS receiver malfunctions the latest values of average wind speed components are saved.

At the same time the difference $\Delta \mathrm{H}$ between the GPS altitude $\left(\mathrm{H}_{\mathrm{G}}\right)$ and the barometric altitude $\left(\mathrm{H}_{\mathrm{B}}\right)$ is computed.

\section{E1. Calculation of the magnetic heading $\Psi_{\mathrm{M}}$}

If the magnetometer is malfunctioning, the magnetic heading used in VOR navigation can be calculated based on the track angle (KD) measured by the GPS, known value of magnetic variation and average value of the drift angle (KZ).

\section{E2. GPS geoid-based altitude calculation}

The altitude indicated by the GPS receiver is measured relative to a reference geoid surface and differs from the altitude above the sea level. If local elevation of the geoid and of the GPS altitude $\left(\mathrm{H}_{\mathrm{G}}\right)$ are known, one can calculate the absolute altitude. In the event of GPS signal loss or if the GPS receiver switches to the $2 \mathrm{D}$ mode, the $\mathrm{H}_{\mathrm{G}}$ altitude is calculated as the sum of the barometric altitude $\left(\mathrm{H}_{\mathrm{B}}\right)$ and the average altitude difference $\Delta \mathrm{H}$.

\section{E3. Ground speed $\left(\mathrm{GS}_{\mathrm{E}}\right)$ and the track angle $\left(\mathrm{KD}_{\mathrm{E}}\right)$ estimates}

If GPS receiver signals are not available, the ground speed is calculated as the sum of the true airspeed TAS $=\mathrm{V}_{\mathrm{T}}$ and the average wind speed. It is most convenient to perform these calculations using TAS and wind speed components in geographic system of reference. Current estimated track angle $\mathrm{KD}_{\mathrm{E}}$ can be calculated from the following dependency:

$$
\mathrm{KD}_{\mathrm{E}}=\arctan \left(\frac{\mathrm{GS}_{\mathrm{EE}}}{\mathrm{GS}_{\mathrm{NE}}}\right) ; \quad \mathrm{GS}_{\mathrm{EE}}=\mathrm{V}_{\mathrm{T}} \cos (\Psi)+\mathrm{U}_{\mathrm{EE}} ; \quad \mathrm{GS}_{\mathrm{NE}}=\mathrm{V}_{\mathrm{T}} \sin (\Psi)+\mathrm{U}_{\mathrm{NE}}
$$

In each case when navigation angles (track angle, heading) are calculated, it is necessary to use a function that will standardize the angle value to the $(0,359.9)$ range.

\section{E4. Calculation of the geographic heading $\Psi_{E}$ based on measurements of the magnetic heading}

If the AHRS module is not calculating the geographic heading, the estimated value of this angle can be estimated as a sum of the magnetic heading $\Psi_{\mathrm{M}}$, the magnetic variation constant $\Delta \mathrm{M}$ and the magnetic deviation of the magnetometer $\Delta \mathrm{B}$, dependent on the current heading. The value of the magnetic variation and the function describing the variation change shall be entered as inputs 
to the estimation algorithm.

\section{E5. Instrument airspeed (IAS), true airspeed (TAS) and outside air temperature ( $t_{S}$ ) estimates}

In case of ADC malfunction, the true airspeed (TAS) can be estimated as the difference of the ground speed and the average wind speed. The outside air temperature is calculated as the sum of the latest temperature measurement and the gradient resulting from the altitude change (assuming that the a temperature gradient for altitude is fixed).

In order to determine the estimated instrument airspeed $\left(\mathrm{V}_{\mathrm{IE}}\right)$, one may use the $\mathrm{H}_{\mathrm{G}}$ altitude determined by the GPS receiver, and the empirical dependency valid for standard change of temperature with altitude [1]:

$$
\mathrm{V}_{\mathrm{IE}}=\frac{\mathrm{V}_{\mathrm{TE}}}{1+\mathrm{k}_{\mathrm{H}} \mathrm{H}_{\mathrm{G}}} ; \quad \mathrm{k}_{\mathrm{H}}=5.74 * 10^{-5} ; \quad \mathrm{H}_{\mathrm{G}}[\mathrm{m}]
$$

The value of the instrument airspeed is necessary in order to preserve operational constraints, e.g. pertaining to the minimum airspeed.

\section{E6. Dead reckoning}

Loss of GPS receiver signals necessitates dead reckoning of the traveled flight path based on the measured true airspeed (TAS), geographic heading $\Psi$ and wind speed components. Calculation of ground speed components in the geographic system of reference allows to compute a change of geographic coordinates (longitude and latitude) since the latest correctly-determined location, while taking into consideration the radius of the appropriate meridian and parallel on the globe. In case of the light aircraft which is being considered here, the effect of flight altitude may be disregarded.

\section{E7. Calculation of the geographic heading $\Psi_{\mathrm{E}}$ based on GPS measurements}

In case of a faulty magnetometer and lack of angular speeds, the geographic heading can be determined using the method described in the case E3, using the ground speed, the track angle and wind speed components.

\section{E8. Roll angle estimate $\Phi_{E}$ - measurement of the angular speed of roll}

The equilibrium of forces in a steady turn implies a relation between the roll angle $\Phi$, the angular speed of the roll $(r)$ and the ground speed $V_{G S}=G S$, which permits estimation of the roll angle $\Phi_{\mathrm{E}}$ :

$$
\begin{aligned}
& \Phi_{\mathrm{E}}=\operatorname{arctg}\left(\frac{\mathrm{r}_{\mathrm{Z}} * \mathrm{~V}_{\mathrm{GS}}}{\mathrm{g}}\right) ; \mathrm{g}-\text { gravitational acceleration } \\
& \mathrm{r}_{\mathrm{Z}}=\mathrm{r}^{*} \cos (\Theta) * \cos \left(\Phi_{\mathrm{E}}\right) \quad \text { - vertical component of the angular speed of yaw }
\end{aligned}
$$


When the angular speed of yaw can not be measured, in order to determine the estimated roll angle $\Phi_{\mathrm{E}}$ one may use a derivative of the track angle $\Psi_{\mathrm{G}}=\mathrm{KD}$ :

$$
\Phi_{\mathrm{E}}=\operatorname{arctg}\left(\frac{\mathrm{d} \Psi_{\mathrm{G}}}{\mathrm{dt}} \frac{\mathrm{V}_{\mathrm{GS}}}{\mathrm{g}}\right) \quad \mathrm{g}-\text { gravitational acceleration }
$$

\section{E10. Estimate of the roll angle $\Phi_{E}$ - measurement of the magnetic heading $\Psi_{M}$}

If the angular speed of yaw is not measured correctly and if no information from the GPS receiver is available, the approximated value of the roll angle $\Phi_{E}$ may be calculated based on the true airspeed $\mathrm{V}_{\mathrm{T}}=\mathrm{TAS}$ and based on the derivative of the magnetic heading $\Psi_{\mathrm{M}}$ :

$$
\Phi_{\mathrm{E}}=\operatorname{arctg}\left(\frac{\mathrm{d} \Psi_{\mathrm{M}}}{\mathrm{dt}} \frac{\mathrm{V}_{\mathrm{T}}}{\mathrm{g}}\right) \quad \mathrm{g}-\text { gravitational acceleration }
$$

\section{E11. Estimate of the pitch angle $\Theta_{E}$ - measurement of the longitudinal acceleration $a_{x}$}

In quasi-established flight states, the pitch angle $\Theta$ can be estimated based on the gravitational acceleration component projected onto the lengthwise axis of the aircraft's system of reference $\mathrm{a}_{\mathrm{x}}$. The estimation error may be reduced by taking into consideration a change of the true airspeed $\mathrm{V}_{\mathrm{T}}$ :

$$
\Theta_{E}=\arcsin \left(\frac{a_{X}-\frac{d V_{T}}{d t}}{g}\right) g-\text { gravitational acceleration }
$$

\section{E12. Estimate of the pitch angle $\Theta_{E}$ - based on the flight path angle and the angle of attack}

If signals from the system of reference and heading are not available, the value of the pitch angle may be estimated based on the calculated flight path angle $\gamma_{\mathrm{E}}$ and based on the calculated angle of attack $\alpha_{E}$ :

$$
\Theta_{\mathrm{E}}=\gamma_{\mathrm{E}}+\alpha_{\mathrm{E}}
$$

The flight path angle $\gamma_{\mathrm{E}}$ is calculated based on the vertical speed (derivative of the $\mathrm{H}_{\mathrm{B}}$ altitude) and true airspeed $\mathrm{V}_{\mathrm{T}}$ :

$$
\gamma_{\mathrm{E}}=\arcsin \left(\frac{\frac{\mathrm{dH}}{\mathrm{dt}}}{\mathrm{V}_{\mathrm{T}}}\right)
$$

The angle of attack $\alpha_{\mathrm{E}}$ is estimated based on the approximated formula resulting from the dependency between flight path angle, the angle of attack and the instrument airspeed $[1,4]$ :

$$
\alpha_{\mathrm{E}}=\frac{\mathrm{B} * \mathrm{a}_{\mathrm{Z}}}{\mathrm{g} * \mathrm{~V}_{\mathrm{I}}^{2} * \cos \left(\gamma_{\mathrm{E}}\right)}
$$

The parameter B is calculated in-flight, when the pitch angle $\Theta$ is measured correctly; its value, 
averaged with a recursive filter, is used for estimation of the angle of attack following the AHRS system failure:

$$
\mathrm{B}=\Theta *\left(\mathrm{~V}_{\mathrm{I}}\right)^{2}
$$

\section{E13. Estimation of barometric altitude $\mathrm{H}_{\mathrm{BE}}$ based on the GPS altitude}

Similarly to the E2 estimate, if the measurement of the barometric altitude is invalid, the barometric altitude estimate $\mathrm{H}_{\mathrm{BE}}$ can be calculated as the difference of the altitude determined by the GPS receiver $H_{G}$ and the previously calculated altitude difference $\Delta H$.

Appropriate computational procedures for state variables' estimation are activated by the diagnostic and reconfiguration system being a part of the integrated measurement subsystem which in turn is a part of the aircraft's on-board control and navigation system. Algorithms were validated by performing test calculations during a flight simulation of the MP-02A Czajka aircraft. For simulation of typical aircraft maneuvers, mathematical models developed in the Department of Avionics and Control System of Rzeszów University of Technology have been used [11,12]. Using "almost perfect" simulated measurements, small software development errors were corrected in functions written in the MATLAB suite and algorithm validity has been confirmed.

\section{EXAMPLES OF ANALYTICAL REDUNDANCY}

In-flight tests allow to ultimately verify correctness of the developed estimation procedures for non-measurable state variables. Actual measurement data, recorded during test flights of the MP-02A Czajka OPV (photo 1) have been used to perform these tests. In the Department of Avionics and Control Systems of Rzeszów University of Technology, several models of control systems and navigation systems for manned aircraft and UAVs have been developed. Work on further systems is under way. The solution presented in the paper is intended for the next version of autopilot software for the MP-02A Czajka aircraft and for other UAVs weighing less than $25 \mathrm{~kg}$. MATLAB scripts will be transposed to the software deployed in control system's microcomputers.

In completed test flights, the output signals of the measurement systems (AHRS with

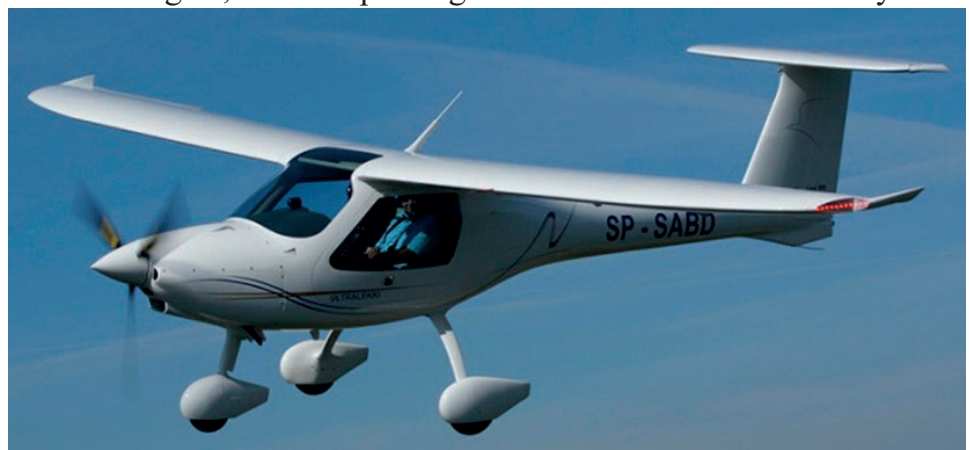

Photo 1. MP-02A Czajka Optionally Piloted Vehicle [courtesy of "Aero-Kros" sp. z o.o. in Krosno] 
magnetometer, ADC, GPS receiver) were recorded with the frequency of $4 \mathrm{~Hz}$ or $10 \mathrm{~Hz}$. The aircraft flew the airfield pattern and to traffic zones. Recorded data files were used to generate a sequence of measurements imitating the data stream occurring in real flight. At any time, it was possible to simulate a fault of a selected measuring sensor, which triggered a corresponding estimation function for the lost variable. The quality of the estimation can been evaluated by comparing the actual measured value with its estimate. The assessment was performed by directly comparing the values of variables (fig. 2-10) and by calculating the mean square error of the estimation.

Figures 2-4 illustrate estimation of the roll angle using various measurement methods

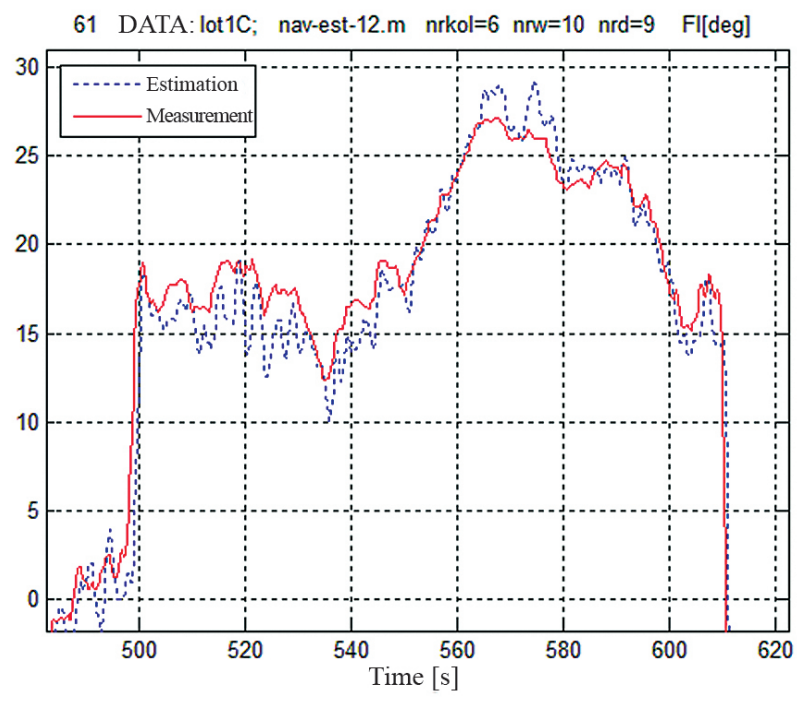

Fig. 2. Roll angle estimate - E8 [Tomczyk, 2015]

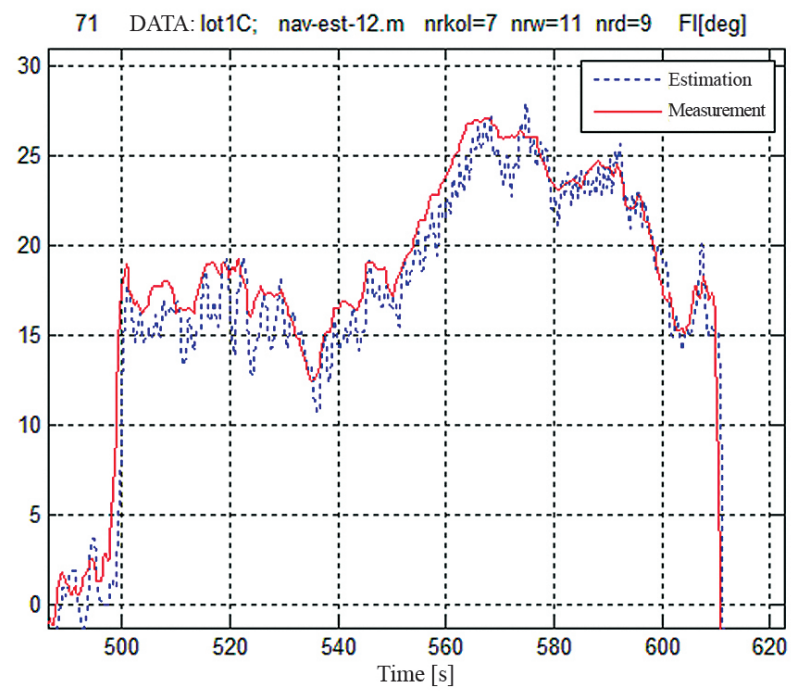

Fig. 3. Roll angle estimate - E9 [Tomczyk, 2015] 
of yaw angular speed. These results are also discussed in [13]. The smallest errors were obtained in case of angular speed measurements (fig. 2), the largest when differentiating the track angle measured by the GPS system (fig. 4). Also large momentary errors occurred during pitch angle estimation (Fig. 5), which resulted from errors of numerical differentiation of flight altitude and delay in angle of attack determination. Filtered value of the pitch angle estimate may be used in the diagnostics system, but is not good for pitch angle control purposes.

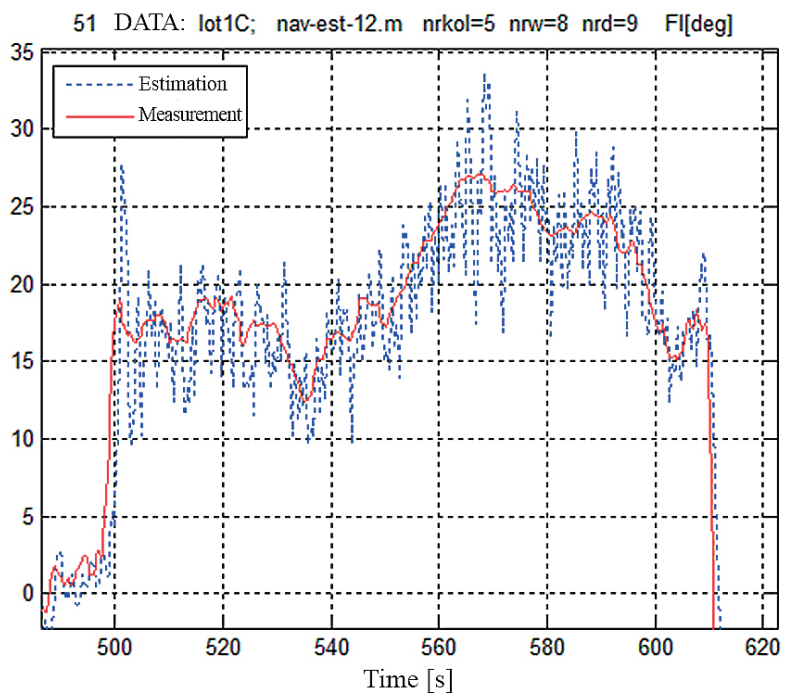

Fig. 4. Roll angle estimate - E10 [Tomczyk, 2015]

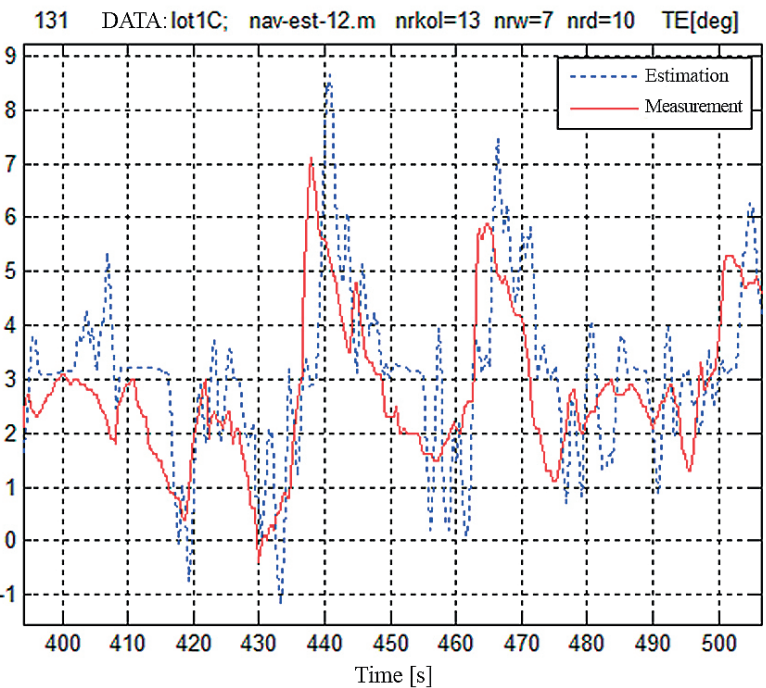

Fig. 5. Pitch angle estimate - E12 [Tomczyk, 2015] 


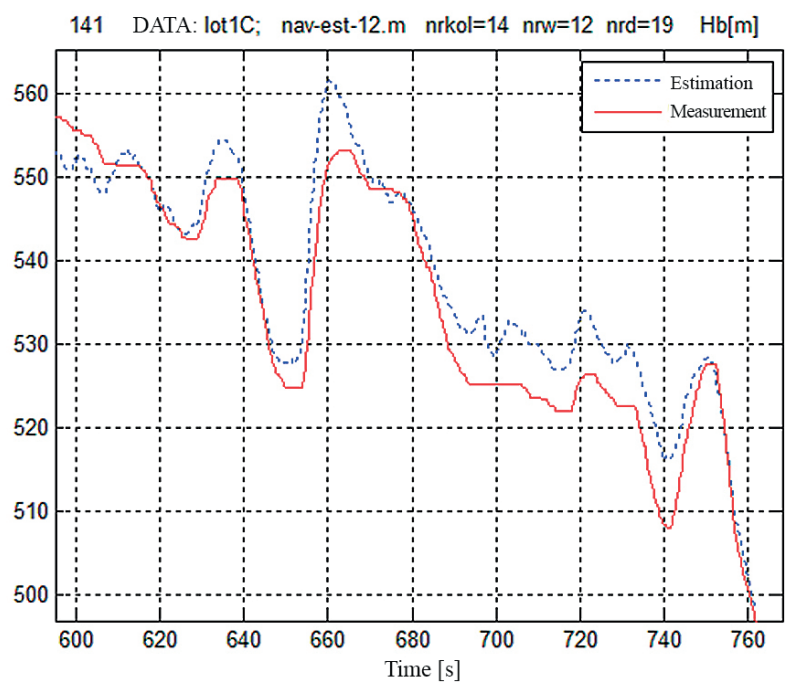

Fig. 6. Barometric altitude estimate - E13 [Tomczyk, 2015]

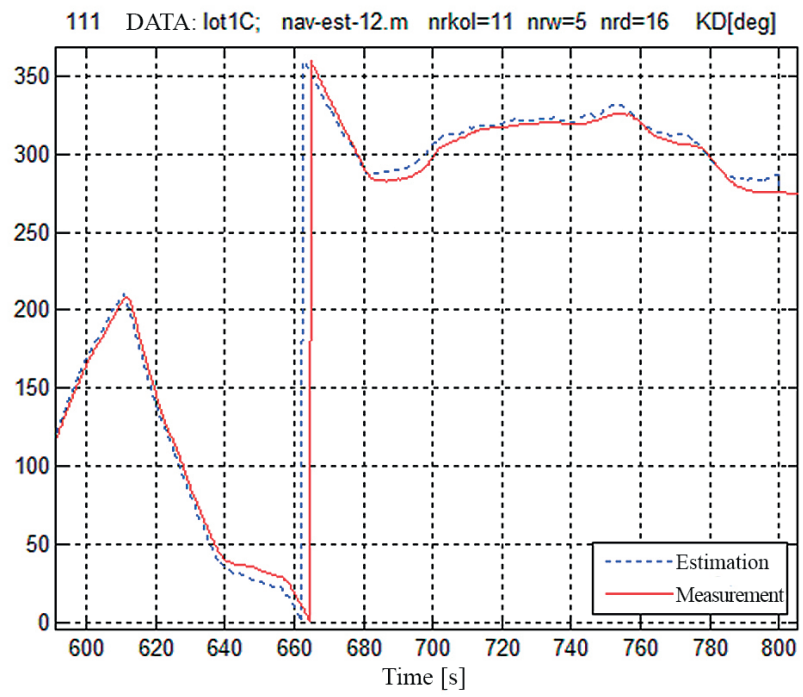

Fig. 7. Track angle estimate - E3 [Tomczyk, 2015]

Figure 6 shows the barometric altitude estimate based on the GPS altitude, whereas fig. 7 shows the track angle calculated based on the magnetic heading. In both cases satisfactory quality of lost measurements' restoration has been achieved.

The estimation error for ground airspeed (GS), estimated based on the true air speed (TAS), depends on the accuracy of wind speed and wind direction estimation, as well as on the momentary heading of the aircraft (fig. 8). The same problem occurs with calculation of the true airspeed based on the speed determined by the GPS system (fig. 9). 


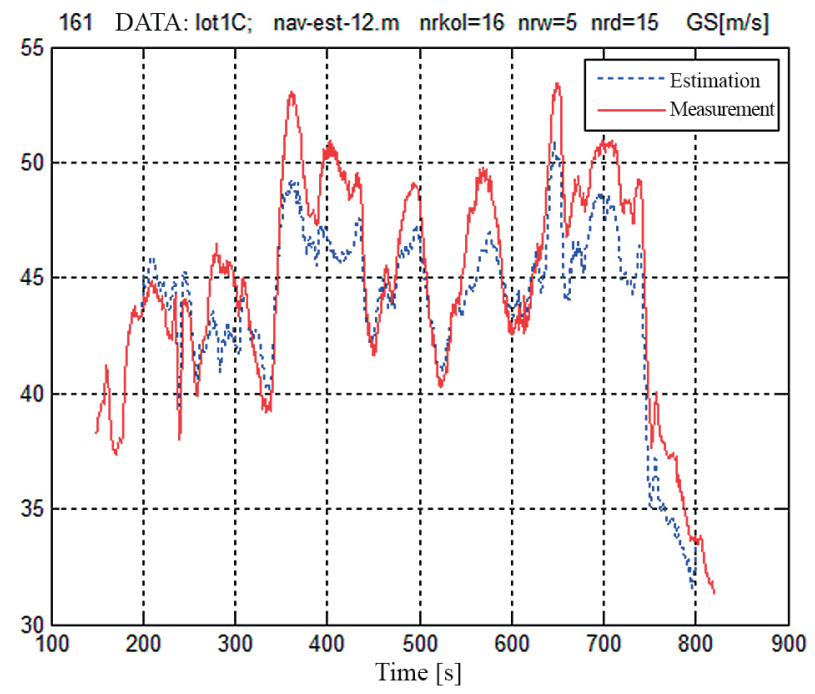

Fig. 8. GS speed estimate - E3 [Tomczyk, 2015]

181 DATA: lot1C; nav-est-12.m nrkol=18 nrw=13 nrd=18 TAS[m/s]

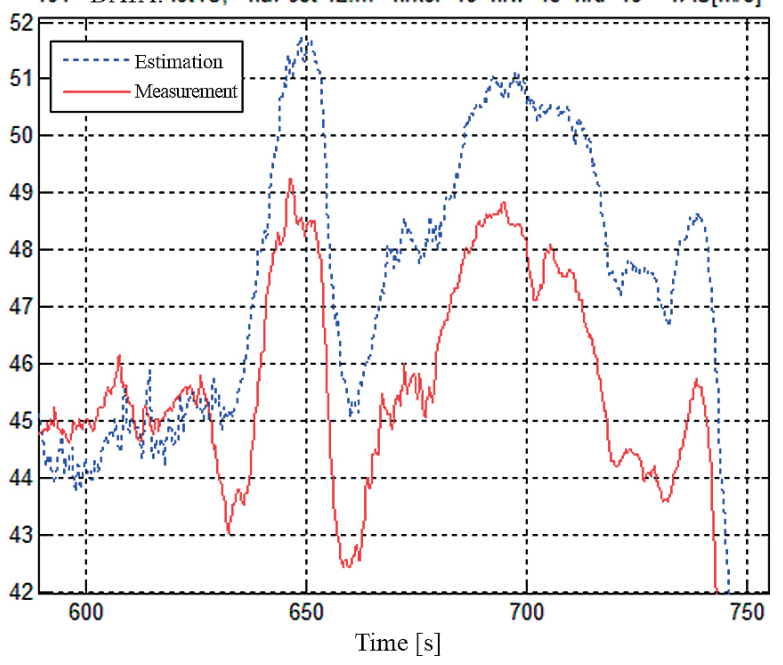

Fig. 9. TAS speed estimate - E5 [Tomczyk, 2015]

Dead reckoning errors, after GPS signal loss, depend on the accuracy of wind speed and wind direction estimation, on the accuracy of the true airspeed and geographic heading measurements and they result from changes of wind speed and wind direction in time. Figure 10a illustrates very good compatibility of the estimated and actual flight path during flight involving a number of turns at a constant altitude. This fragment of the flight lasted 10 minutes. However, the change of the altitude during descent resulted in an increasing error in position determination, reaching up to $1 \mathrm{~km}$, which is illustrated in Figure 10b. 
a)

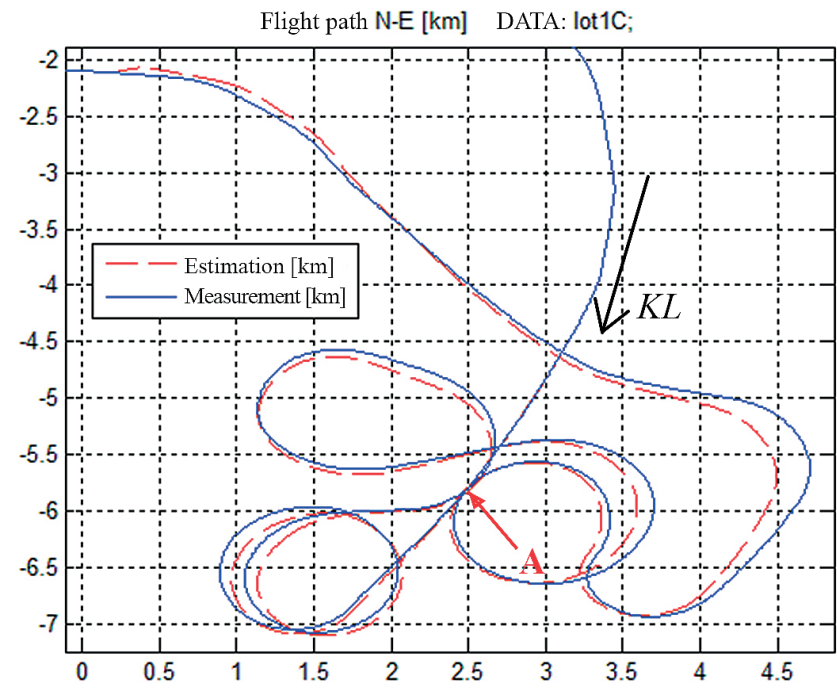

b)

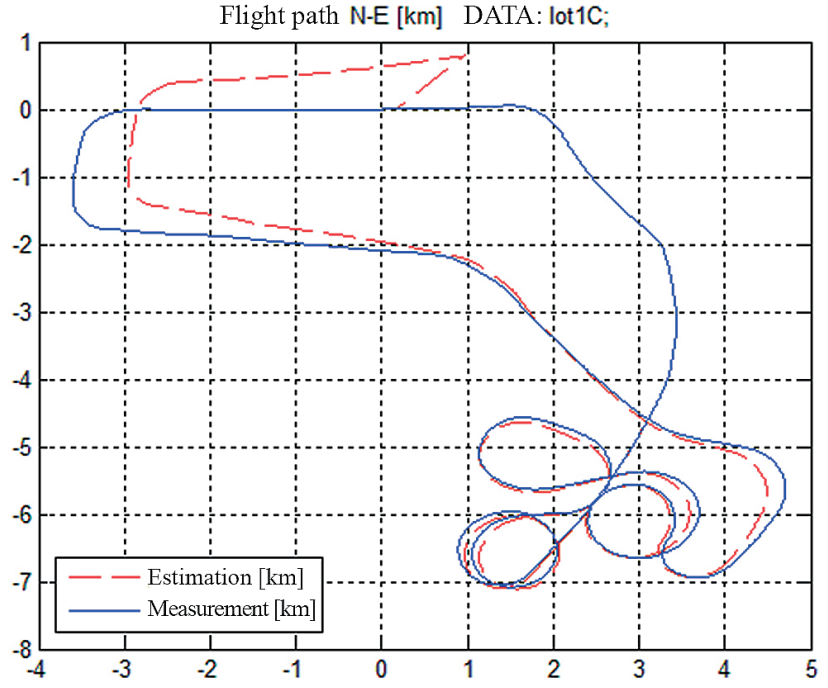

Fig. 10. Flight path estimate - E6; KL - flight direction, A - estimation start point; a) enlarged part of the flight path, b) increasing estimation error during landing approach [Tomczyk, 2015]

The performed calculations precisely follow the computations performed by the real-time on-board measurement system, in case faults of individual sensors are detected. One can, therefore, state that the proposed calculation algorithms accomplish the tasks specified for analytical redundancy modules very well. 


\section{CONCLUSIONS}

Estimation algorithms of non-measurable aircraft state variables presented in this paper allow for implementation of the analytical redundancy, that is calculation of values of selected variables based on the available signals. It was assumed that the simplest estimation methods, implementable in systems with low computing power, will be used. The quality of the estimation varies, yet in the majority of cases it is sufficient for detection of a faulty measuring sensor and in most cases estimated signals can be used for aircraft control in emergency situations. Due to obvious reasons the error of navigational position determination will accumulate in time, as errors of airspeed and track angle are integrated and because wind speed and wind direction do change in real life, which directly contributes to the error of geographic coordinate determination.

\section{REFERENCES}

[1] Battipede, M., Gili, P. A. and Lando, M., 2002, "Virtual air-data sensor calibration through a Canfis model", Paper AIAA 2002-4790, AIAA Modeling and Simulation Technologies Conference and Exhibit, Monterey, CA.

[2] Heller, M., Myschiky, S., Holzapfelz, F. and Sachs, G., 2003, "Low-cost approach based on navigation data for determining angles of attack and sideslip for small aircraft", Paper AIAA 2003-5777, AIAA Guidance, Navigation, and Control Conference and Exhibit, Austin, TX.

[3] Popowski, St., 2007, "Wyznaczanie kąta pochylenia i przechylenia w tanich systemach nawigacji lądowej" (Estimation of pitch and roll angles in low-cost land navigation systems). Zeszyty Naukowe Politechniki Rzeszowskiej (Scientific Journals of Rzeszów University of Technology), No. 238, Mechanika (Mechanics), vol. 71, Rzeszów, pp. 365-372.

[4] Popowski, St., Dąbrowski, W., 2015, „Pomiar i estymacja kąta ślizgu” (Sideslip angle measurements and estimation). Zeszyty Naukowe Wyższej Szkoły Oficerskiej Sił Powietrznych (Scientific Journals of Polish Air Force Academy), 1(24), Dęblin, pp. 9-17.

[5] Dołęga, B., Kopecki, G., Rogalski, T., 2007, „Wybrane przykłady redundancji analitycznej w układach pomiarowych systemu pośredniego sterowania SPS-01" (Selected examples of analytical redundancy in measurement systems of the SPS-01 indirect control system). Zeszyty Naukowe Politechniki Rzeszowskiej (Scientific Journals of Rzeszów University of Technology), Mechanika (Mechanics), 238(71), Rzeszów, pp. 285-292.

[6] Gruszecki, J. [Ed], 2002, „Bezpilotowe aparaty latajace, systemy sterowania i nawigacji” (Unmanned Aerial Vehicles, control and navigation systems). Oficyna Wydawnicza Politechniki Rzeszowskiej (Publishing House of Rzeszów University of Technology), Rzeszów.

[7] Kopecki, G., Pieniążek, J., Rogalski, T., Rzucidło, P. and Tomczyk, A., 2008, “A Proposal of Navigation and Control System for Small UAV". UAV World 2008 Conference, Frankfurt/Main.

[8] Kopecki, G. and Tomczyk, A., 2005, "A Simple Redundancy Method for Pitch and Bank Angles Estimation". SAE-2005-01-3362, SAE World Aerospace Congress, AeroTech Congress \& Exhibition, Dallas/Fort Worth, TX. 
[9] Kopecki, G., Tomczyk, A. and Rzucidlo, P., 2013, “Algorithms of Measurement System for a Micro UAV”. Solid State Phenomena, 198, Mechatronic Systems and Materials IV, pp. 165-170.

[10] Tomczyk, A., 2006, "Simple virtual attitude sensors for general aviation aircraft". Aircraft Engineering and Aerospace Technology: An International Journal, 4(78), pp. 310-314.

[11] Basmadji, F. L., 2014, "Systemy wspomagające naprowadzanie obiektów latających podczas lotu w skonfigurowanym terenie" (Assistance guidance systems for flying objects during a flight in a configured terrain).Ph. D. dissertation, Wydział Budowy Maszyn i Lotnictwa (Faculty of Mechanical Engineering and Aeronautics), Politechnika Rzeszowska (Rzeszów University of Technology).

[12] Cieciński, P., Pieniążek, J., 2015, "Model samolotu MP-02 dla sterowania w locie autonomicznym" (MP-02 aircraft model for autonomous flight control purposes). Zeszyty Naukowe Wyższej Szkoły Oficerskiej Sił Powietrznych (Scientific Journals of Polish Air Force Academy), 1(24), Dęblin, pp. 41-50.

[13] Dołęga, B., Kopecki, G., Tomczyk, A., 2016, "Possibilities of using software redundancy in law cost aeronautical control systems". 3rd IEEE International Workshop in Metrology for Aerospace (MetroAeroSpace), Florence, Italy.

\section{REDUNDANCJA ANALITYCZNA W SYSTEMACH STEROWANIA BEZPILOTOWYMI LUB OPCJONALNIE PILOTOWANYMI STATKAMI POWIETRZNYMI}

\section{Streszczenie}

Artykuł przedstawia główne właściwości modułu estymacji niemierzalnych zmiennych stanu statku powietrznego (stałopłata). Przykładowe obliczenia dotyczą opcjonalnie sterowanego lekkiego samolotu MP-02A Czajka. Jakość oszacowania wartości parametrów lotu obrazuje porównanie zarejestrowanych w rzeczywistym locie parametrów lotu samolotu MP-02A Czajka oraz estymowanych wartości tych parametrów obliczonych dla przypadków symulacji uszkodzenia kolejnych czujników pomiarowych. Eksperyment pozwala ocenić użyteczność mechanizmu redundancji analitycznej dla wyznaczenia parametrów opisujących orientację przestrzenną (kąty przechylenia, pochylenia i kursu) oraz wielkości nawigacyjnych (prędkość i wysokość lotu oraz współrzędne geograficzne).

Słowa kluczowe: pokładowe systemy pomiarowe, redundancja analityczna, BSP, opcjonalnie sterowane statki powietrzne.

This paper was funded by the National Research and Development Center as a task under the research grant No. PBS2/B6/19/2013. 